\title{
Performance evaluation of an anaerobic hybrid reactor treating petrochemical effluent
}

\author{
M.T. Jafarzadeh*,Manager of Environment, \\ National Petrochemical Company, Tehran, I.R. Iran., \\ Jafarzaadeh@yahoo.com \\ N. Jamshidi, HSE Training Manager, \\ National Petrochemical Company, Tehran, I.R. Iran., \\ Naserjam@yahoo.com
}

\author{
L. Talebiazar, Senior Expert of Environment Lab., \\ AmirKabir University of Technology, Tehran, I.R. Iran., \\ ltalebiazar@yahoo.com \\ R.Aslaniavali, Senior Expert of Environment, \\ AFA Company, Tehran, I.R.Iran. \\ $\underline{\text { R_Aslani@gmail.com }}$
}

\begin{abstract}
Organic loading rate (OLR), Hydraulic Retention Time (HRT) and up flow velocity are important parameters significantly affecting microbial ecology and characteristics of anaerobic reactors. In this study, Performance of an anaerobic hybrid reactor (UASB/Filter) at mesophilic condition was evaluated in a $15.4 \mathrm{~L}$ reactor receiving petrochemical wastewater. The temperature of influent was adjusted by an inline heat exchanger at around $35{ }^{\circ} \mathrm{C}$. The reactor was seeded with flocculent sludge from a UASB plant treating dairy wastewater. The sludge was acclimatized to petrochemical wastewater in twostage operation. After 39 weeks, a COD reduction of $70.3 \%$ was obtained at OLR $=2.0 \mathrm{~kg} \mathrm{~m}^{-3} \mathrm{~d}^{-1}$ and HRT $=18 \mathrm{~h}$.

Under steady state conditions, experiments were conducted at OLRs of between 0.5 and $24 \mathrm{~kg}$ TCOD $\mathrm{m}^{-3} \mathrm{~d}^{-1}$, hydraulic retention times (HRT) of 4-48 h and up flow velocities 0.021-0.25 $\mathrm{m} \mathrm{h}^{-1}$. Removal efficiencies in the range of $42-86 \%$ were achieved at feed TCOD concentrations of $1000-4000 \mathrm{mg} \mathrm{L}^{-1}$. The biogas production data used for determination of biogas production kinetics. The values of Gmax and GB estimated as 11.173 $\mathrm{LL}^{-1} \mathrm{~d}^{-1}$ and $85.83 \mathrm{~g} \mathrm{~L}^{-1} \mathrm{~d}^{-1}$, respectively.
\end{abstract}

Keywords-Hybrid; Industrial wastewater; Petrochemical; Anaerobic treatment

\section{INTRODUCTION}

The petrochemical industry poses a significant environmental impact by discharging effluent to receiving waters containing (hardly) biodegradable organic matter. Aerobic processes are not regarded as a suitable treatment option because of high energy requirements for aeration, limitations in liquid-phase oxygen transfer rates, and large quantities of sludge production. Traditional anaerobic processes are also limited by low rates of organic matter removal, long hydraulic retention times (HRT), accumulation of excessive residual organic matter and intermediate products, and large reactor volume requirements. Recent developments in anaerobic treatment processes, especially high retention of biomass in the reactor, has made it possible to decouple solids retention time (SRT) and hydraulic residence time in high-rate anaerobic reactors. This has resulted in increased treatment efficiency of these processes and gradual but steady improvement of the common perception that anaerobic processes are not suitable for treatment of various industrial effluents.

Increase in yearly production capacity from 5.9 million tons in 1990 to 125 million tons until 2025, either due to construction of new plants or expansion of existing petrochemical plants in IRAN, resulted in more quantity and higher strength of wastewater. The type of wastewaters treated by anaerobic technology in the world is completely different from wastewater produced by petrochemical industries in IRAN. So that the major part of studies on anaerobic treatment or constructed anaerobic plants for petrochemical wastewater focused on PET or PTA plants but there is only one plant in IRAN that produce PET and PTA. On the other hand some petrochemical complexes are concentrated in a region named petrochemical zones that the wastewater from all complexes will be treated at one common wastewater treatment plant. This will result in more difference between the qualities and compounds of wastewater treated by anaerobic technology in here and that in other countries.

Several anaerobic reactors have been successfully applied to the treatment of various industrial wastes [1]. According to a report published in 1990 from some companies that made anaerobic reactors, there were more than 1330 anaerobic reactors in the world [1]. But it is important to note that the majority of the reactors $(76 \%)$ were used in food industries. Since last 10 years only their use in other industries such as petrochemical industry has started [1]. From 1330 reactors, only 80 reactors are used for chemical wastewater treatment and from these 80 reactors only 33 reactors (less than $2.5 \%$ of all reactors) used in petrochemical industries that of 27 reactors are used for PET and PTA wastewater treatment. From reactors used for treatment of petrochemical wastewater, 9 reactors were hybrid and of that 8 of them used in PET and PTA wastewater treatment.

Several authors reported that up to a certain limit, the treatment efficiency of complex wastewaters, in high rate anaerobic reactors increases with increasing OLR. A further increase of OLR will lead to operational problems like sludge 
bed flotation and excessive foaming at the gas-liquid interface in the gas-liquid-solid (GLS) separator, as well as accumulation of undigested ingredients. As a result, the treatment efficiency deteriorates [2,3,4]. Also accumulation of biogas in the sludge bed was noticed, forming stable gas pockets that lead to incidental lifting of parts of the bed and a pulse- like eruption of the gas from this zone [4,5]. As we know, the applied organic loading rate (OLR) is related to hydraulic retention time (HRT) and waste COD concentration. For this reason, OLR is an inadequate design parameter to assure well performance of anaerobic reactors. James C.Young [6] reported that HRT was the most important parameter affecting COD removal performance. Wang [7] reported that, during anaerobic sewage treatment in a $170 \mathrm{~m}^{3}$ hydrolysis up flow sludge bed (HUSB) reactor, HRT in the range $(2.5-5 \mathrm{~h})$ does not seriously affect the removal rate of the suspended solids. Differently, GonÇalves et al. [8] show that the removal efficiency decreased with decreasing HRT accompanied by increase of up flow velocities. It might be argued that the HRT is an inadequate parameter for describing solids removal in up flow reactors. The effect of HRT could manifest as a result of its direct relation to the liquid up flow velocity $\left(\mathrm{V}_{\text {up }}\right)$ and also to the solids contact time in the reactor and so the possibility of solids to coalesce or to be entrapped in the sludge bed. Moreover, the HRT is a major parameter, which determines the SRT [9]. The SRT can indirectly influence the solids removal as through changing of the physical-chemical and biological characteristics of the sludge bed in addition to biogas production.

The up flow velocity is one of the main factors affecting the efficiency of up flow reactors $[8,10,11]$. The up flow velocity affects the sludge retention as it is based on the settling characteristics of sludge aggregates. Therefore, the up flow velocity could be a restrictive factor with respect to the required reactor volume when treating very low strength wastewater and wastewaters with high suspended solids [11]. The up flow velocity has two opposing effects. On one hand, increasing up flow velocity increases the rate of collisions between suspended particles and the sludge and thus might enhance the removal efficiency. On the other hand, increasing the up flow velocity could increase the hydraulic shearing force, which counteracts the removal mechanism through exceeding the settling velocity of more particles and detachment of the captured solids and consequently deteriorates the removal efficiency.

A wide range of organic and hydraulic loading rates has been reported in the literature for anaerobic reactors, depending on the substrate used and the quality and quantity of the microbial community. Syutsubo et al. [12] reported a COD loading of $45 \mathrm{~kg} \mathrm{COD} \mathrm{m}^{-3} \mathrm{~d}^{-1}$ with a COD removal efficiency of $90 \%$ at sludge loading rates (SLRs) of up to $3.7 \mathrm{~g} \mathrm{COD} \mathrm{g}^{-1}$ $\mathrm{VSS} \mathrm{d}^{-1}$ for thermophilic reactors [13]. Organic loading rates (OLR) of up to $104 \mathrm{~kg} \mathrm{COD} \mathrm{m}^{-3} \mathrm{~d}^{-1}$ have been reported for anaerobic digestion of sugar substrate under thermophilic conditions [14]. According to Soto et al. [15], excellent stability and high treatment efficiency was achieved with hydraulic residence times as low as $2 \mathrm{~h}$ at an OLR of $6 \mathrm{~kg}$ COD m ${ }^{-3} \mathrm{~d}^{-1}$, the percent COD removals being $95 \%\left(30^{\circ} \mathrm{C}\right)$ and $92 \%\left(20^{\circ} \mathrm{C}\right)$. Borja and Banks [16] reported COD removal efficiencies of $64-99 \%$ at OLR values of $12-17 \mathrm{~kg}^{-3}$ OD m $\mathrm{m}^{-3} \mathrm{~d}^{-1}$. Higher OLR values of up to $45 \mathrm{~kg}$ COD m $\mathrm{m}^{-3} \mathrm{~d}^{-1}$ have been reported only for hybrid reactors using a combination of UASB reactor and a bentonite packing as a biomass support [17].

GonÇalves et al. [8] treated sewage anaerobically at $20{ }^{\circ} \mathrm{C}$ in an up flow anaerobic reactor (no GLS) operated at up flow velocities of $3.2,1.7,1.6,0.9,0.75$ and $0.6 \mathrm{~m} \mathrm{~h}^{-1}$, corresponding to HRTs of $1.1,2.1,2.3,2.8,3.3$ and $4.3 \mathrm{~h}$, respectively. They showed deterioration of removal efficiency as up flow velocity increases, varying from a value of $70 \% \mathrm{SS}$ removal at 0.75 and $0.9 \mathrm{~m} \mathrm{~h}-1$ to $51 \%$ at $3.4 \mathrm{~m} \mathrm{~h}^{-1}$. The removal efficiency at an up flow velocity of $0.60 \mathrm{~m} \mathrm{~h}^{-1}$ was, contradictory to these observations, only $60 \%$ because of starting of methane production due to increase of HRT and accordingly the SRT. An increase in up flow velocity from 1.6 to $3.2 \mathrm{~m} \mathrm{~h}^{-1}$ resulted in a relatively small loss in SS removal efficiency, from $55 \%$ to nearly $50 \%$, which indicates the role of adsorption and entrapment $[8,9]$.

Petrochemical wastewater contains some nondegradable, toxic or inhibitor components that influence on reactor performance and its applicable organic loading rates. This may limit the operation to OLRs of less than $1.0 \mathrm{~kg} \mathrm{COD} \mathrm{m}^{-3} \mathrm{~d}^{-1}$. Kleerebezem [18] reported 90\% COD removal efficiency for a reactor treating PET effluents at OLR $=22 \mathrm{~kg} \mathrm{COD} \mathrm{m}^{-3} \mathrm{~d}^{-1}$. Others have reported 52-90\% COD removal efficiency for reactors treating PET effluents at $\mathrm{OLR}=4.8-9.0 \mathrm{~kg}^{\mathrm{COD} \mathrm{m}} \mathrm{d}^{-3} \mathrm{~d}^{-1}$ [19-22]. Also M.De et al., [23] reported 97\% COD removal efficiency for a hybrid reactor treating PCP and some organic acids at PCP concentration 2-21 $\mathrm{mg} \mathrm{L}^{-1}$.

In this study, the effect of organic and hydraulic loading rates on hybrid reactor treating petrochemical effluent was investigated at different influent COD concentrations. Also, the effect of up flow velocity on the reactor performance was studied. These are important parameters and only limited information is available about the steady-state performance of hybrid reactors treating petrochemical effluents.

\section{MATERIALS AND METHODS}

\section{A. Location}

This study was conducted from December 2009 to June 2012 in a petrochemical plant in south of IRAN. In this complex, variety of products including chemicals and polymers are produced.

\section{B. Experimental setup}

In this study, a Plexiglas column $(15 \mathrm{~cm}$ in diameter and $120 \mathrm{~cm}$ in height) was used as the anaerobic hybrid reactor. The upper $20 \mathrm{~cm}$ of the reactor was operated with fixed bed of corrugated plastic sheet with $170 \mathrm{~m}^{2} \mathrm{~m}^{-3}$ specific surface areas. The total volume of the reactor was $18.5 \mathrm{~L}$ and the volume of 
liquid was 15.4 lit. Recycle, being designed only for emergency conditions, such as clogging of the distribution system, was not used continuously during the experimental study. There aren't any solids/liquid/gas separation devices in the reactor. The schematic diagram of the model reactor is given in Fig.1.

The reactor was operated under mesophilic conditions and temperature of the influent flow adjusted to $35^{\circ} \mathrm{C}$ by a heat exchanger before entering to the reactor. Also two automatically adjustable heating devices placed at the bottom and middle of the reactor adjusted the temperature of the liquid inside the reactor.

\section{Feed}

There is an existing wastewater treatment plant (WTP) in this petrochemical complex. This WTP consists of some physicochemical units followed by an activated sludge system for treatment of wastewater. The output of API oil separator entered to the reactor. Because of increase in the production capacity of the existing plants, the flow and strength of wastewater was increased more than the WTP design criteria. Basic composition of wastewater is presented in table 1 .

Biological treatment processes require macronutrients such as nitrogen as nitrate or ammonium salts and phosphorus as phosphorus salts for bacterial metabolism, growth, activity and stability of process. Also, all methanogns use ammonia as nitrogen source [24]. The TCOD:N:P ratio of the wastewater is 1726:45.2:1.5 or 700:18.33:0.61. But the suitable TCOD: N: P ratio for anaerobic is about 700:5:1 [25]. The comparison of these two ratios shows that the amount of phosphorus is low. Thus, phosphoric acid is added to wastewater for compensating phosphorus.

\section{Seeding}

The use of appropriate seed is very important at the start up of the reactor. Because sufficient seed quality will result in process stability and minimize the start up period. In IRAN, anaerobic process is nowhere used to treat petrochemical waste. Hence, there is no seed culture that is acclimatized to this type of wastewater. Therefore the reactor was seeded with flocculent sludge from a UASB Plant treating dairy wastewater.

\section{E. Start up}

The results of BOD tests at different dilutions and comparing the curves with typical BOD curves showed that there is a lag period and increase in the toxicity to bacteria to degrade petrochemical wastes, thus it is necessary to adapt the microbial cells to these wastes.

At the beginning of this study (before measuring of BOD values), the reactor was run for 5 months without adaptation but it was unsuccessful. So it was considered to adapt the sludge in two stages. In the first stage, the synthetic wastewater made from dry milk was fed to the reactor. Then in second stage, concentration of COD was increased in the feed at $10 \%$ increment per cycle till it reached $100 \%$.

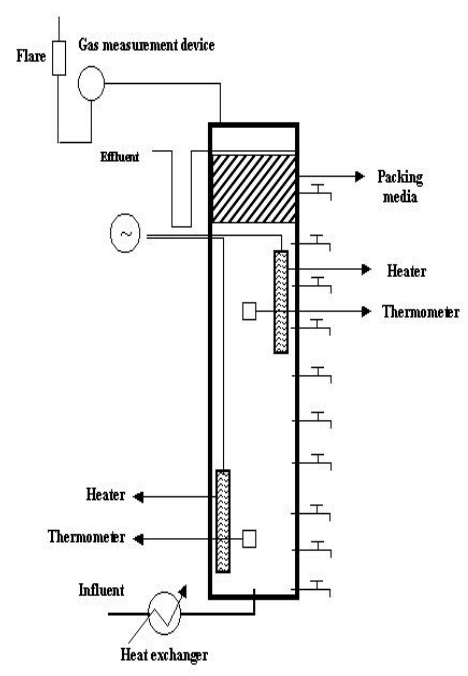

Fig 1. Schematic diagram of the hybrid model reactor.

TABLE 1. Basic composition of wastewater from the Petrochemical complex after API oil separator

\begin{tabular}{lclc}
\hline \multicolumn{1}{c}{ Parameter } & Average & $\begin{array}{l}\text { Standard } \\
\text { Deviation }\end{array}$ & $\begin{array}{c}\text { Number } \\
\text { of samples }\end{array}$ \\
\hline $\mathrm{pH}$ & 6.12 & 3.46 & 590 \\
$\mathrm{~T},{ }^{\circ} \mathrm{C}$ & 34.5 & 1.19 & 145 \\
${ }^{*} \mathrm{COD}_{\text {tot }}, \mathrm{mg} \mathrm{L}^{-1}$ & 2075 & 1075 & 590 \\
$\mathrm{COD}_{\text {tot }}, \mathrm{mg} \mathrm{L}^{-1}$ & 1726 & 846 & 590 \\
$\mathrm{COD}_{\mathrm{Sus}} / \mathrm{COD}_{\text {tot }}$ & 0.856 & 0.102 & 53 \\
$\mathrm{BOD}_{5} / \mathrm{COD}^{-1}$ & 0.684 & 0.107 & 19 \\
$\mathrm{BOD}_{20} / \mathrm{COD}^{-1}$ & 0.776 & 0.123 & 19 \\
$\mathrm{TDS} \mathrm{mg} \mathrm{L}^{-1}$ & 672 & 232.5 & 53 \\
$\mathrm{TKN}, \mathrm{mg} \mathrm{L}^{-1}$ & 45.2 & 34.8 & 53 \\
$\mathrm{TP}, \mathrm{mg} \mathrm{L}^{-1}$ & 1.5 & 1.25 & 53 \\
Alkalinity, mg L & 366 & 56.4 & 53 \\
\hline Before API separator unit & & &
\end{tabular}

\section{F. Operational conditions}

After successful start-up was completed on week 40, the influent COD concentration changed stepwise from 1000 to $4000 \mathrm{mgL}^{-1}$. At each COD changing steps, the HRT of the reactor changed from 48 to $24,12,8$ and $4 \mathrm{hr}$, respectively that resulted in different OLRs. By changing the hydraulic retention time and influent COD concentrations, 25 different operational conditions were applied and COD removal efficiencies measured after reaching to hydraulically steady state conditions. When hydraulically steady state conditions were reached, changing to other HRTs were tired. The influent and effluent COD concentration among the reactor operation time are shown in Fig.2. 
The criteria for hydraulic steady state were the following: (a) an operation period of more than 10 times the HRT (and more than 2 weeks) [26]; and (b) variations in effluent concentration lower than $\pm 10 \%$ [27]. Elmitwalli [28] and Mahmoud [29] also considered these criteria satisfactory. A real steady state would only be achieved in the sludge bed, and consequently in the reactor, if the operation period is at least three SRTs [30].

\section{G. Analytical methods}

Samples of the influent and effluent of the model reactor were taken and analyzed according to Standard Methods for the Examination of Water and Wastewater [31]. pH, COD, alkalinity and biogas volume were measured daily. The COD concentration was determined by the colorimetric method, using a spectrophotometer Hacth DR2010 at wavelength 640 nm. The $\mathrm{pH}$ value was measured with $692 \mathrm{pH}-$ meter metrohm. Gas production rates were measured using volume displacement method.

\section{H. Experimental design}

The experimental protocol was designed to examine the effect of different OLRs, HRTs and up flow velocities on the operational and performance of the reactor. All experiments were performed under hydraulically steady state conditions.

\section{RESULTS AND DISCUSSION}

\section{A. Startup}

The startup of the reactor was relatively long because the system had not been adapted to the petrochemical wastes previously. After 30 weeks, adaptation period had been completed and a COD removal of $70.3 \%$ was obtained at $\mathrm{OLR}=2.0 \mathrm{kgm}^{-3} \mathrm{~d}^{-1}$ and HRT $=18 \mathrm{~h}$.

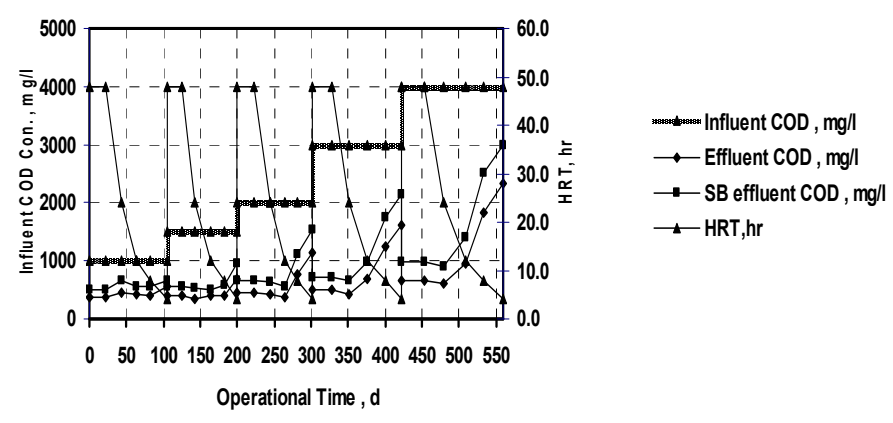

Figure 2. Influent and effluent COD concentration among the reactor operation time

\section{B. Steady state performance}

The influent and effluent COD of the reactor during the operation period, and the results for different organic and hydraulic loading rates along with performance indicators are presented in Table 2.

\section{1) Removal efficiency}

The performance of the experimental hybrid reactor based on total COD removals at various HRTs and OLRs is shown in Figures 3 and 4, respectively. Also, the performance of the reactor at various up flow velocities is shown in Fig. 5. The COD reduction of the system ranging from 42.1 to $85.9 \%$ was achieved. The maximum COD reduction is obtained at influent COD concentration of $3000 \mathrm{mg} \mathrm{L}^{-1}, \mathrm{HRT}=24 \mathrm{~h}$ and $\mathrm{OLR}=3.0 \mathrm{~kg} \mathrm{~m}^{-3} \mathrm{~d}^{-1}$. The minimum COD reduction is obtained at influent COD concentration of $4000 \mathrm{mg} \mathrm{L}^{-1}, \mathrm{HRT}=4 \mathrm{hr}$ and $\mathrm{OLR}=24 \mathrm{~kg} \mathrm{~m}^{-3} \mathrm{~d}^{-1}$. The COD reduction at about average COD concentration of this petrochemical complex $\left(1726 \mathrm{mg} \mathrm{L}^{-1}\right)$ was ranging between 43.4-80.9 \% depends on operational conditions (Table 2).

\section{2) Hydraulic retention time}

The results of the reactor performance versus HRT (Fig.3) showed that the reduction of COD reached to a maximum at $\mathrm{HRT}=24 \mathrm{~h}$ and then decreased gradually with increase of HRT. It can be the result of decrease in biogas production and up flow velocities that resulted in lower mixing and contact between substrate and biomass. At certain HRT, the TCOD reduction will increase by increasing the influent COD concentration because of more biogas production resulted in more agitation and contact between substrate and biosolids, as shown in fig.3.

$-\mathrm{S} 0=1000 \mathrm{mg} / \mathrm{l} \longrightarrow \mathrm{S} 0=1500 \mathrm{mg} / \mathrm{l} \triangle \mathrm{S} 0=2000 \mathrm{mg} / \mathrm{l} \rightarrow \mathrm{S} 0=3000 \mathrm{mg} / \mathrm{l} \rightarrow \mathrm{S} 0=4000 \mathrm{mg} / \mathrm{l}$

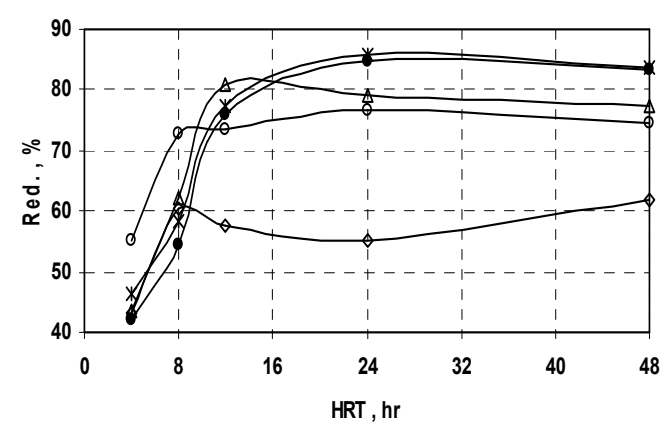

Figure 3. Variation of TCOD removal efficiencies at different HRTs 
TABLE 2. Summary of the conditions during the operation period of the experimental setup

\begin{tabular}{|c|c|c|c|c|c|c|c|}
\hline $\begin{array}{l}\text { Phase of } \\
\text { study }\end{array}$ & $\begin{array}{c}\text { Time } \\
\text { d }\end{array}$ & $\begin{array}{c}\mathrm{C}_{0} \\
\operatorname{mg~L^{-1}}\end{array}$ & $\begin{array}{c}\text { HRT } \\
\text { h }\end{array}$ & $\begin{array}{c}\text { OLR } \\
\mathrm{kg} \mathrm{m}^{-3} d^{-1}\end{array}$ & $\begin{array}{c}\mathbf{V}_{\text {up }} \\
\mathbf{m ~ h}^{-1}\end{array}$ & $\begin{array}{l}\text { Effluent COD } \\
\mathrm{mg} \mathrm{L}^{-1}\end{array}$ & $\begin{array}{c}\text { COD Red. } \\
\%\end{array}$ \\
\hline \multirow{5}{*}{1} & \multirow{5}{*}{$1-105$} & \multirow{5}{*}{1000} & 48 & 0.50 & 0.021 & 381 & 61.9 \\
\hline & & & 24 & 1.00 & 0.042 & 448 & 55.2 \\
\hline & & & 12 & 2.00 & 0.083 & 423 & 57.7 \\
\hline & & & 8 & 3.00 & 0.125 & 396 & 60.4 \\
\hline & & & 4 & 6.00 & 0.250 & 568 & 43.2 \\
\hline \multirow{5}{*}{2} & \multirow{5}{*}{$106-200$} & \multirow{5}{*}{1500} & 48 & 0.75 & 0.021 & 385 & 74.3 \\
\hline & & & 24 & 1.50 & 0.042 & 353 & 76.5 \\
\hline & & & 12 & 3.00 & 0.083 & 398 & 73.5 \\
\hline & & & 8 & 4.50 & 0.125 & 408 & 72.8 \\
\hline & & & 4 & 9.00 & 0.250 & 675 & 55.0 \\
\hline \multirow{5}{*}{3} & \multirow{5}{*}{$201-301$} & \multirow{5}{*}{2000} & 48 & 1.00 & 0.021 & 456 & 77.2 \\
\hline & & & 24 & 2.00 & 0.042 & 418 & 79.1 \\
\hline & & & 12 & 4.00 & 0.083 & 383 & 80.9 \\
\hline & & & 8 & 6.00 & 0.125 & 756 & 62.2 \\
\hline & & & 4 & 12.00 & 0.250 & 1133 & 43.4 \\
\hline \multirow{5}{*}{4} & \multirow{5}{*}{$302-422$} & \multirow{5}{*}{3000} & 48 & 1.50 & 0.021 & 493 & 83.6 \\
\hline & & & 24 & 3.00 & 0.042 & 423 & 85.9 \\
\hline & & & 12 & 6.00 & 0.083 & 681 & 77.3 \\
\hline & & & 8 & 9.00 & 0.125 & 1248 & 58.4 \\
\hline & & & 4 & 18.00 & 0.250 & 1614 & 46.2 \\
\hline \multirow{5}{*}{5} & \multirow{5}{*}{$423-560$} & \multirow{5}{*}{4000} & 48 & 2.00 & 0.021 & 669 & 83.3 \\
\hline & & & 24 & 4.00 & 0.042 & 608 & 84.8 \\
\hline & & & 12 & 8.00 & 0.083 & 965 & 85.0 \\
\hline & & & 8 & 12.00 & 0.125 & 1822 & 54.5 \\
\hline & & & 4 & 24.00 & 0.250 & 2316 & 42.1 \\
\hline
\end{tabular}

\section{3) Organic loading rate}

The results of the reactor performance versus OLR are shown in fig.4. It can see from this figure that up to a certain limit, the treatment efficiency increases with increasing OLR depend on influent COD concentration. The results showed that reduction of COD reached to a maximum at OLRs ranging 2.5 to $3.7 \mathrm{~kg} \mathrm{~m}^{-3} \mathrm{~d}^{-1}$. A further increase of OLR by increasing the HRT and influent COD concentration resulted in less COD reduction because of biosolids wash out.

As shown in fig.4, at certain OLR, same to HRT effect, the TCOD reduction will increase by increasing the influent COD concentration because of more biogas production resulted in more agitation and contact between substrate and biosolids. The applied organic loading rate is related to the HRT and influent substrate concentration. Using applied loading rate alone as a process parameter, by doubling the OLR while holding the influent concentration constant, would be expected to decrease efficiency by -5 to $43 \%$. Young [6] found this value by about $18-15 \%$.

\section{4) Up flow velocity}

As shown in figure 5, constant up flow velocity, the reduction performance increase with $\mathrm{COD}$ concentration increasing, because of more agitation and contact between biosolids and substrate resulted from more biogas production. The maximum COD reduction of about $85 \%$ achieved at up flow velocity ranging $0.02-0.04 \mathrm{mh}^{-1}$ and COD concentration of $3000 \mathrm{mgL}^{-1}$. Increasing of up flow velocity resulted in biomass wash out in the effluent because the biosolids are flocculent type nor granular.
$-\mathrm{S} 0=1000 \mathrm{mg} / \mathrm{l} \rightarrow \mathrm{S} 0=1500 \mathrm{mg} / \mathrm{l} \rightarrow-\mathrm{S} 0=2000 \mathrm{mg} / \mathrm{l} \rightarrow \mathrm{SO}=3000 \mathrm{mg} / \mathrm{l} \rightarrow-\mathrm{S} 0=4000 \mathrm{mg} / \mathrm{l}$

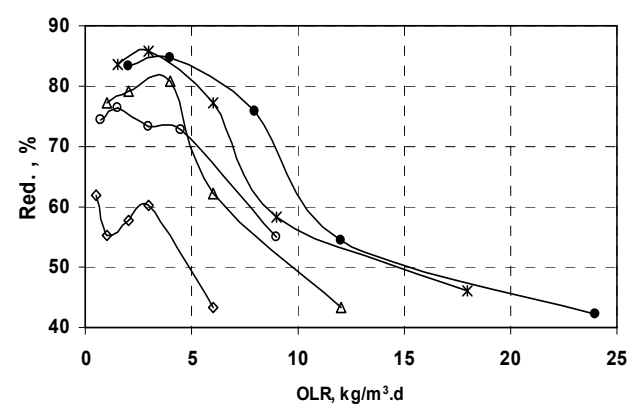

Figure 4. Variation of TCOD removal efficiencies at different OLRs

Also, at constant COD concentration, the reduction performance decrease with increasing of up flow velocity because increasing the up flow velocity could increase the hydraulic shearing force, which counteracts the removal mechanism through exceeding the settling velocity of more particles and detachment of the captured solids and consequently deteriorates the removal efficiency.

\section{5) Biogas production}

Biogas production is an important parameter for anaerobic treatment systems. The specific biogas production rate versus the organic loading rate is plotted in fig.6, which 
$\longrightarrow$ Vup $=0.021 \mathrm{~m} / \mathrm{h} \rightarrow-$ Vup $=0.042 \mathrm{~m} / \mathrm{h} \rightarrow-$ Vup $=0.083 \mathrm{~m} / \mathrm{h}$

* Vup $=0.125 \mathrm{~m} / \mathrm{h} \rightarrow-$ Vup $=0.250 \mathrm{~m} / \mathrm{h}$

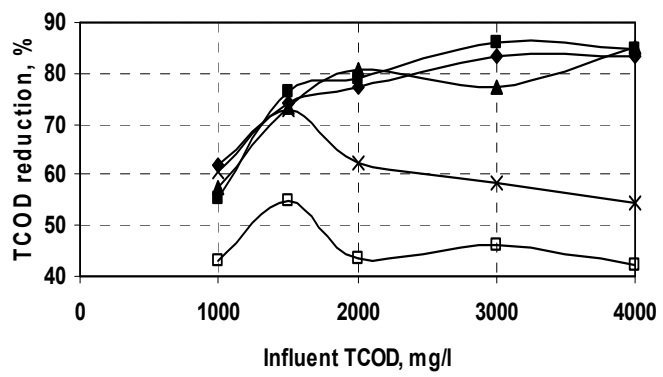

Figure 5. Variation of TCOD removal efficiencies at different up flow velocities

confirms that the biogas production rate was a function of the organic loading rate and that it could be described similarly to organic substrate removal kinetics [32].

The biogas production rate can be expressed as follows:

$$
G=\frac{G_{\max }\left(Q S_{i} / V_{r}\right)}{G_{B}+\left(Q S_{i} / V_{r}\right)}
$$

Where, $G$, is specific biogas production rate $\left(L^{-1} d^{-1}\right)$, Gmax is maximum specific biogas production rate $\left(\mathrm{LL}^{-1} \mathrm{~d}^{-1}\right)$, $\mathrm{QSi} / \mathrm{Vr}$, is organic loading rate $\left(\mathrm{g} \mathrm{L}^{-1} \mathrm{~d}^{-1}\right)$ and GBis constant value. The inverse of the biogas production rate is plotted against the inverse of the OLR; a straight line portion of intercept and slope of line gives $1 / \mathrm{Gmax}$ and $\mathrm{GB} / \mathrm{Gmax}$, respectively.

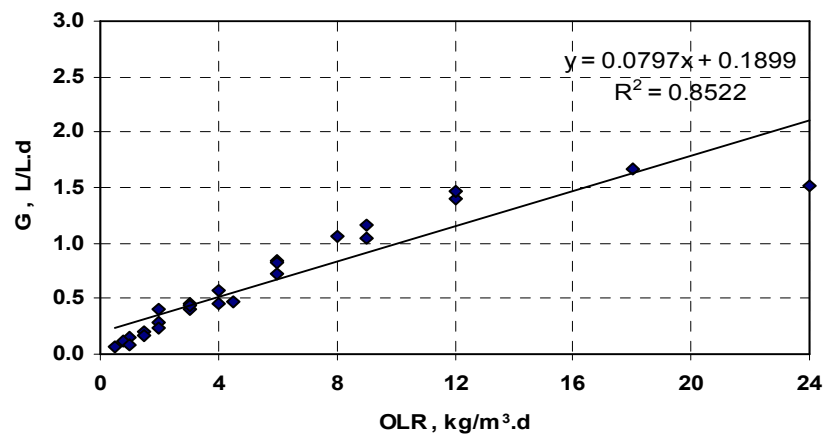

Figure 6. Specific biogas production rate versus the organic loading rate

This graph is given in figure 7. From this figure, Gmax and GB can be estimated as $11.173 \mathrm{LL}^{-1} \mathrm{~d}^{-1}$ and $85.83 \mathrm{~g} \mathrm{~L}^{-1} \mathrm{~d}^{-1}$ respectively with high correlation coefficient $(\mathrm{R} 2=0.90)$, respectively. Buyukkamaci and Filibeli [33] found these values as $33.3 \mathrm{LL}^{-1} \mathrm{~d}^{-1}$ and $88.45 \mathrm{~g} \mathrm{~L}^{-1} \mathrm{~d}^{-1}$ for synthetic substrate made from molasses, respectively. Therefore, the above equation comes to this form:

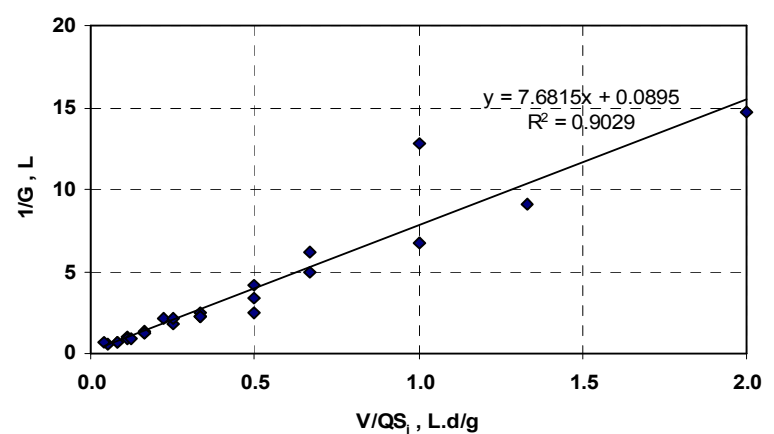

Figure 7. Determination of biogas production kinetic constants

$$
G=\frac{11.17\left(Q S_{i} / V_{r}\right)}{85.83+\left(Q S_{i} / V_{r}\right)}
$$

\section{CONCLUTIONS}

The startup results showed that there is a lag period for starting up the reactor; therefore, it is necessary to acclimatize the seed sludge to the petrochemical feed. The results of the study showed petrochemical wastewater can be satisfactorily treated by means of high-rate anaerobic processes, specifically with the use of hybrid reactor. High TCOD removals of between 42 and $86 \%$ at OLRs of 0.5 $24.0 \mathrm{~kg} \mathrm{COD} \mathrm{m}^{-3} \mathrm{~d}^{-1}$ and HRTs between 4 and $48 \mathrm{~h}$ were achieved in this study. The maximum specific biogas production rate of $11.17 \mathrm{LL}^{-1} \mathrm{~d}^{-1}$ was in the same order of magnitude as the rates achieved in earlier studies.

\section{REFERENCES}

[1] Macarie H. "Overview of the application of anaerobic treatment to chemical and petrochemical wastewaters", Journal of Water Science and Technology, 2000:42:5-6:201-214

[2] Sayed S. K. I.,Anaerobic treatment of slaughterhouse wastewater using the UASB process. Ph.D. thesis, Department of Environmental Technology, Wageningen University, Wageningen, The Netherlands, 1987.

[3] Ruiz I., Veiga M. C., Santiago P. de and Blàzquez R. Treatment of slaughterhouse wastewater in a UASB reactor and an anaerobic filter. Biores. Technol., 1997:60:251-258.

[4] Kalyuzhnyi S., Santos L. E. de los and Martinez J. R. Anaerobic treatment of raw and preclarified potato-maize wastewaters in a UASB reactor. Biores. Technol., 1998:66:195-199.

[5] Elmitwalli T. A., Zandvoort M., Zeeman G., Bruning $\mathrm{H}$. and Lettinga G. Low temperature treatment of domestic sewage in upflow anaerobic sludge blanket and anaerobic hybrid reactors. Water Sci. Technol., 1999:9(5):177-185.

[6] Young,J.C. "Factors affecting the design and performance of upflow anaerobic filters", Water Science and Technology , 1991:24:8:133-155. 
[7] Wang Kaijun, Integrated anaerobic and aerobic treatment of sewage. Ph.D. thesis, Department of Environmental Technology, Wageningen University, Wageningen, The Netherlands, 1994.

[8] GonÇalves R. F., Cha Lier A. C. and Sammut F. Primary fermentation of soluble and particulate organic matter for waste water treatment. Water Sci. Technol., 1994:30 (6):53-62.

[9] Zeeman G., Sanders W. T. M., Wang K. Y. and Lettinga G. (1996). Anaerobic treatment of complex wastewater and waste activated sludge- application of an upflow anaerobic removal (UASR) reactor for the removal and pre-hydrolysis of suspended COD. IAWQ-NVA conference for 'Advanced wastewater treatment', 2325.9.96.

[10] Metcalf and Eddy, Wastewater Engineeringtreatment and reuse, 4th edn., McGraw Hill, New York, USA 2003

[11] Wiegant W. M. , Experiences and potential of anaerobic wastewater treatment in tropical regions. Water Sci. Technol.,2001:44(8):107-113.

[12] Syutsubo K, Harada H, Ohashi A, Suzuki H. Effective start-up of thermophilic UASB reactor by seeding mesophilically-grown granular sludge. Water Sci Technol 1997;36(6-7):391-8.

[13] Syutsubo K, Harada H, Ohashi A. Granulation and sludge retainement during start-up of a thermophilic UASB reactor. Water Sci Technol 1998;38(8-9 part):349-57.

[14] Wiegant WM, Lettinga G. Thermophilic anaerobic digestion of sugars in an upflow anaerobic sludge blanket reactors. Biotechnol Bioeng 1985;27:1603-7.

[15] Soto M, Ligero P, Vega A, Ruiz I, Veiga MC, Blazquez R. Sludge granulation in UASB digesters treating low strength wastewaters at mesophilic and psychrophilic temperatures. Environ Technol 1997;18(11):1133-41.

[16] Borja R, Banks CJ. Performance and kinetics of an upflow anaerobic sludge blanket (UASB) reactor treating slaughterhouse wastewater. J Environ Sci Health 1994;A29:2063-85.

[17] Borja R, Banks CJ, Wang Z. Performance of a hybrid anaerobic reactor, combining a sludge blanket and a filter, treating slaughterhouse wastewater. Appl Microbiol Biotechnol 1995;43:351-7.

[18] Kleerebezem R. , J.Mortier , L.W.Hulshoff Pol and G.Lettinga, Anaerobic Pretreatment of a Petrochemical Wastewater- Terphetalic Acid Wastewater ", Journal of Water Science and Technology, 1997:36:2-3:237-248.

[19] Macarie H. "Anaerobic Treatment of a Wastewater of a Petrochemical plant producing an aromatic compound, terphtalic acid ", $\mathrm{PhD}$ thesis, 1992.

[20] Young,J.C., Kim, I.S., Page, I.C., Wilson, D.R., Brown, G.J. and Cocci, A.A. "Two stage treatment of purified terphtalic acid production wastewaters", Water Science and Technology , 2000:42:5-6:277-282.
[21] Page, I.C., Cocci, A.A., Grant, S.R., Wilson, D.R. and Landine, R.C. "Single stage anaerobic hybrid treatment of a polyester intermediate production wastewater." Prepint. Int. Conf. Waste minimization and End of Pipe Treatment in Chemical and Petrochemical industries, 14-18 November, Merida, Yucatan, Mexico, 1999:529-532.

[22] Page, I.C., Wilson, D.R., Cocci, A.A.. and Landine, R.C. "Anaerobic hybrid treatment of terphtalic acid wastewater." Proc. 71 st Annual Water Environment Federation Conf., 3-7 October 1998 , Orlando, Florida: 575586.

[23] M.De Almedia Prado Montenegro, E.De Mattos Moraes, H.Moreria Soares and R.Filomena Vazoller, "Hybrid reactor performance in pentachlorophenol (PCP) removal by anaerobic granules", Journal of water Science and Technology,Vol.44 ,No.4, 2011, pp.137-144.

[24] Singh R.P., Surendra Kumar, Ojha C.S.P, Nutrient requirement for UASB process, A review, Biochemical Engineering Journal, 1999:3:35-54.

[25] Bitton, Gabriel , 2nd edition, Wastewater Microbiology, John Wiley and sons Ltd, 1999, ISBN:0471320471, 330-348.

[26] Noyola, A., Capdeville, B., and Roques, H., Anaerobic treatment of domestic sewage with a rotating stationary fixed-film reactor, Water Research, 1988: (22)12:1585-1592.

[27] Polprasert, C., Kemmadamnrong, P., and Tran, F.T., Anaerobic baffle reactor (ABR) process for treating slaughterhouse wastewater, Environmental Technology 1992:13:857-865.

[28] Elmitwalli, T.A. Anaerobic treatment of domestic sewage at low temperature, Ph.D. thesis, 2009, Wageningen University, Wageningen, the Netherlands.

[29] Mahmoud, N.J.A., Anaerobic pre-treatment of sewage under low temperature $(15 ! \mathrm{C})$ conditions in an integrated UASB-digester system, Ph.D. thesis, Wageningen University, Wageningen, The Netherlands, 2002.

[30] van Haandel, A.C. and Lettinga, G. (1994), Anaerobic sewage treatment. A practical guide for regions with a hot climate, John Wiley \& Sons Ltd., Chichester, England.

[31] Standard Methods for the Examination of Water and Wastewater, 22th Edition. American Public Health association (APHA), American Water Works Association (AWWA) and Water Environment Federation (WEF). Washington DC, USA, 2012.

[32] Yu H., Wilson F. and Tay J., Kinetic analysis of an anaerobic filter treating soybean wastewater, Water Research, 1998:32:11:3341-52.

[33] Buyukkamaci N. \& Filibeli A. Determination of kinetic constant of an anaerobic hybrid reactor, Process Biotechnology, 2002:38:73-79.

\section{Creative Commons Attribution License 4.0 (Attribution 4.0 International, CC BY 4.0)}

This article is published under the terms of the Creative Commons Attribution License 4.0

https://creativecommons.org/licenses/by/4.0/deed.en US 